\title{
Comparative serology techniques for the diagnosis of Trypanosoma cruzi infection in a rural population from the state of Querétaro, Mexico
}

\author{
María Elena Villagrán-Herrera'1/+ , Manuel Sánchez-Moreno² , Adriana Jheny Rodríguez-Méndez ${ }^{1}$,

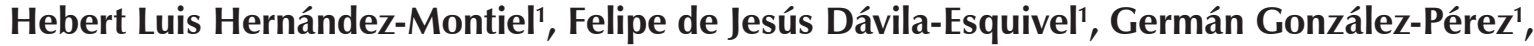 \\ José Alejandro Martínez-Ibarra ${ }^{3}$, José Antonio de Diego-Cabrera ${ }^{4}$
}

\begin{abstract}
1Departamento de Investigación Biomédica, Facultad de Medicina, Universidad Autónoma de Querétaro, Santiago de Querétaro, Querétaro, México ${ }^{2}$ Departamento de Parasitología, Facultad de Ciencias, Universidad de Granada, Granada, España ${ }^{3}$ Área de Entomología Médica, Centro Universitario del Sur, Universidad de Guadalajara, Ciudad Guzmán, Jalisco, México ${ }^{4}$ Departamento de Medicina Preventiva y Salud Pública, Facultad de Medicina, Universidad Autónoma de Madrid, Madrid, España
\end{abstract}

Immunological diagnostic methods for Trypanosoma cruzi depend specifically on the presence of antibodies and parasitological methods lack sensitivity during the chronic and "indeterminate" stages of the disease. This study performed a serological survey of 1,033 subjects from 52 rural communities in 12 of the 18 municipalities in the state of Querétaro, Mexico. We detected anti-T. cruzi antibodies using the following tests: indirect haemagglutination assay (IHA), indirect immunofluorescence assay (IFA), ELISA and recombinant ELISA (rELISA). We also performed Western blot (WB) analysis using iron superoxide dismutase (FeSOD), a detoxifying enzyme excreted by the parasite, as the antigen. Positive test results were distributed as follows: ELISA 8\%, rELISA 6.2\%, IFA and IHA 5.4\% in both cases and FeSOD 8\%. A comparative study of the five tests was undertaken. Sensitivity levels, specificity, positive and negative predictive values, concordance percentage and kappa index were considered. Living with animals, trips to other communities, gender, age, type of housing and symptomatology at the time of the survey were statistically analysed using SPSS software v.11.5. Detection of the FeSOD enzyme that was secreted by the parasite and used as an antigenic fraction in WBs showed a 100\% correlation with traditional ELISA tests.

Key words: Trypanosoma cruzi - iron superoxide dismutase (FeSOD) - rural zones - Querétaro

Chagas disease is a primary public health issue in Latin America. The World Health Organization (WHO) states that approximately eight million persons are infected in Latin America and an additional 20 million people are at risk of contracting the infection (Miles 2004).

The first methods that were used to identify Chagas disease included the complement fixation test, which was used by Guerrero and Machado in 1913, as well as the identification of unilateral conjunctivitis and Romana's sign (OMS 1991, OPS 1993, Miles 2004).

Historically, the possibility of transmission via blood transfusion was first described by Mazza et al. (1936), followed nine years later by Días (1945) in Brazil and by Bacigalupo (1945) in Argentina. Talice (1947) in Uruguay reported a related study.

Reactive blood donors were diagnosed for the first time in 1949 using the complement fixation test in Belo Horizonte (Pellegrino 1949) and São Paulo, Brazil (Faria 1951, Freitas et al. 1952).

doi: 10.1590/0074-0276130413

Financial support: PROMEP, UAQ

+ Corresponding author: mevh@uaq.mx

Received 22 August 2013

Accepted 18 August 2014
Treatment of potentially infected donor blood using crystal violet dye was proposed at approximately the same time (Nussenzweig et al. 1953).

The risk of transmission of Chagas disease via blood transfusion is largely due to the following factors: (i) hundreds of donors are infected, but asymptomatic and the stage or phase of the disease is not known, (ii) donors come from geographical areas in which Chagas disease is endemic (Guzmán-Bracho et al. 1998), (iii) serum-reactive donors are not detected at blood banks, (iv) symptoms of the disease in its chronic phase are mistaken for less severe pathologies, (v) no serological analyses are performed in urban areas or the analyses lack the appropriate sensitivity and specificity, (vi) transmission can occur by other routes, such as organ transplants, bone marrow transplants, accidents in the clinical laboratory and orally, (vii) congenital transmission, (viii) frequent immigration of persons from endemic zones to regions where the vector insect is not present and (ix) lack of vector control strategies, adequate epidemiological data and awareness of Chagas disease as a public health issue (Castro 2009).

Control measures have been implemented during the last 20 years in Latin America, with a resulting drop in the prevalence of transmission by blood transfusions (Castro 2009).

During the acute phase of the disease, antibody identification is possible by the fourth week after infection. The minimum standard for establishing an acute phase diagnosis is the documentation of serum conversion 
(from negative to positive) by conventional serological testing of two paired serum samples obtained less than one month apart. Parasitaemias are transitory during the chronic phase and parasite detection in blood is completely random with low sensitivity. The diagnosis is based on a finding of anti-Trypanosoma cruzi antibodies in the bloodstream (Lorca et al. 1990).

Conventional serological tests alone are not sufficient, mainly because antigenic preparations are derived from parasite extracts or semi-purified fractions of epimastigotes (the non-infectious form of the parasite) and procedures differ between laboratories. Therefore, inconclusive results are frequently obtained (Berrizbeitia et al. 2012). However, some patients with Chagas disease have false negative results (Kirchhoff \& Neva 1985, Araújo \& Berne 2013). The WHO recommends the use of three assays because of the aforementioned inconveniences and variations in the sensitivity of serological screening in blood banks and individual diagnoses. ELISA, indirect haemagglutination assays (IHA) and recombinant (rELISA) or indirect immunofluorescence assays (IFA) are used for the diagnosis of Chagas disease (NOM 1999, Foti et al. 2009). An infected person with reactive serum must undergo at least two serological assays (Foti et al. 2009).

This practice is mandatory in Argentina and enforcement began in Brazil in December 2002. Monteón-Padilla et al. (1999) demonstrated that the IHA technique has a very low sensitivity and is not a reliable test in blood donors. ELISA is therefore recommended for screening samples at blood banks; however, an ELISA test that employs recombinant antigens or synthetic peptides (Longhi et al. 2012) and demonstrates high sensitivity and specificity should be used (OMS 1990, 1991).

Similarly, an epidemiological profile for the studied communities must be designed to evaluate variables in the population under study, such as housing type, cohabitation with animals, trips outside the communities of origin, symptomatology during the survey, age and age distribution and gender (OMS 1991). This information will render an accurate profile of the rural localisation of this endemic disease, which is crucial for Mexico (Guzmán-Bracho 2001).

\section{SUBJECTS, MATERIALS AND METHODS}

Population studied - A total of 1,033 blood samples were drawn from subjects from 51 rural communities in 12 of the 18 municipalities in the state of Querétaro. Sampling was based on reports of an existing vector (Villagrán et al. 2008), housing conditions, co-habitation with animals and seropositivity (as reported by blood bank-based ELISA testing) (CETS 2002).

The sample size was calculated using the statistical program Epi Info v.2002. Statistical analyses of frequencies and statistical significance were performed using SPSS 11.5 software.

The Committee of Bioethics and Research of the University of Granada, Spain approved this study.

Blood sampling - Blood samples were drawn during the epidemiological interview from the cubital vein of either the right or left forearm after the area was disinfected and cleaned using a cotton pellet soaked with a mixture of $5 \%$ glycerol in ethanol. Blood samples were collected in glass vacuum containers $(7 \mathrm{~mL})$ containing gel that inhibited blood clotting and prevented haemolysis. This precaution was important because samples were frequently moved during transportation to the laboratory. Blood was centrifuged at $5,000 \mathrm{rpm}$ for $10 \mathrm{~min}$ to separate serum from the globular fraction. Serum was stored in five $50-\mu \mathrm{L}$ aliquots and frozen at $-20^{\circ} \mathrm{C}$ until used.

Serological assays - Determination of antibody expression in the 1,033 serum samples was performed using conventional assays. Total extracts of the epimastigote forms of T. cruzi (BioMérieux ${ }^{\circledR}$ ) were used for ELISA testing and cut-off points were established for each series of sera studied (Lorca et al. 1990). rELISA (Wiener ${ } \mathrm{lab}^{\circledR}$ ) employed six antigens synthesised from trypomastigote and epimastigote fragments from various T. cruzi strains (SAPA, 1, 2, 13, 30 and 36) (Longhi et al. 2012). Reactivity at dilutions $>1: 8$ was considered positive for IHA (Wiener lab ${ }^{\circledR}$ ). The Camargo method was employed for IFA, using complete forms of T. cruzi epimastigotes isolated from strain Y (of Brazilian origin) and strain T3 (of Mexican origin, state of Veracruz, derived from in vitro cultures in Grace medium). Samples with titres > 1:16 were considered positive (Camargo et al. 1986, Berrizbeitia et al. 2012).

New diagnostic techniques - The iron superoxide dismutase (FeSOD) method uses the isoenzyme FeSOD as an immunogenic protein for $T$. cruzi. This protein is extracted from the epimastigote and trypomastigote forms, which were isolated from the Colombian strain and cultured in vitro in Grace medium (Sigma ${ }^{\circledR}$ ) supplemented with $10 \%$ bovine foetal serum $(\mathrm{v} / \mathrm{v})\left(\mathrm{Gibco}^{\circledR}\right)$ that had been previously heat inactivated at $56^{\circ} \mathrm{C}$ for $30 \mathrm{~min}$. Flagellates were cultivated in $3 \mathrm{~mL}$ of medium in $25-\mathrm{cm}^{2}$ plastic Roux flasks (Corning) at $28^{\circ} \mathrm{C}$ at an initial concentration of $5 \times 10^{4}$ cells $/ \mathrm{mL}$. Cultures were centrifuged at $1,500 \mathrm{rpm}$ for $10 \mathrm{~min}$ when the cellular concentration reached approximately $2 \times 10^{7}$ cells $/ \mathrm{mL}$ (counted in a Neubauer haemocytometer chamber). The resulting pellet was rinsed twice in phosphate-buffered saline and centrifuged. The extracted enzyme was purified, fractioned and used as an antigen in Western blots to detect anti-T. cruzi antibodies in the 1,033 serum samples. The test was considered to be positive when anti-T. cruzi antibodies were detected at a dilution of 1:80 (Marín \& Sánchez-Moreno 2010, Berrizbeitia et al. 2012). Evaluations of statistically significant differences between the tests were based on sensitivity, specificity, negative and positive predictive values, concordance percentage and the kappa index. The following epidemiological variables were considered in this study: presence of the vectors Triatoma mexicana $(94 \%)$, Triatoma dimidiate $(3 \%)$, Triatoma gerstaeckeri (2\%) and Triatoma pallidipennis (1\%) (Villagrán et al. 2009), gender, age, housing type, co-habitation with animals, trips outside the community and reported symptomatology that was compatible with known signs and symptoms of the acute or chronic phases of Chagas disease. Comparisons between epidemiologic parameters and survival patterns were established in every studied population (Ferrer et al. 2013). Statistical analyses were performed using SPSS v.11.5 to 
measure confidence values and statistical significance between parameters.

These data were collected using an epidemiological survey, which was completed at the time of blood sample collection.

\section{RESULTS AND DISCUSSION}

The five immunological tests were performed in 1,033 samples and yielded the following percentages of positive findings: ELISA $8 \%$, rELISA $6.2 \%$ and IHA and IFA $5.4 \%$. The $8 \%$ positive rate for FeSOD testing was consistent with the results of the most commonly used antibody test (Fig. 1, Table I).

All serological techniques are used primarily during the latent and chronic stages of infection, when it is difficult to identify the parasites. Cross-reactivity of Chagas disease tests with circulating antibodies related to other infections and diseases, such as leishmaniasis, malaria, toxoplasmosis, hepatitis, leprosy, syphilis and

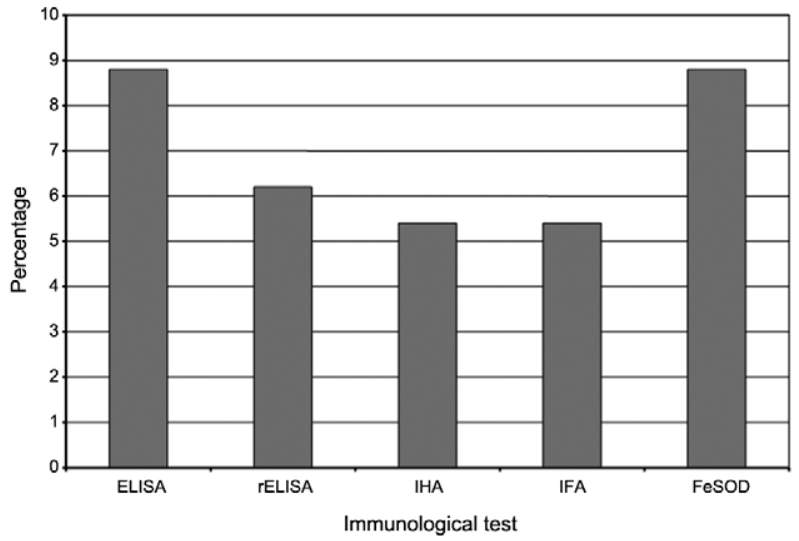

Fig. 1: immunological tests applied to samples of the studied individuals in rural communities in the state of Querétaro, Mexico. FeSOD: iron superoxide dismutase; IFA: indirect immunofluorescence assay; IHA: indirect haemagglutination assay; rELISA: recombinant ELISA.

TABLE I

Seroreactive tests at Trypanosoma cruzi in population of different communities of the state of Querétaro, México

\begin{tabular}{|c|c|c|c|c|c|c|c|c|}
\hline \multirow[b]{2}{*}{ Municipalities } & \multirow[b]{2}{*}{ Rural communities } & \multicolumn{5}{|c|}{$\begin{array}{l}\text { Seroreactive } \\
\text { (n) }\end{array}$} & \multirow{2}{*}{$\begin{array}{l}\text { Seropositivity } \\
\text { at two tests } \\
\text { (n) }\end{array}$} & \multirow{2}{*}{$\begin{array}{l}\text { Total persons } \\
\text { sampled } \\
\text { (n) }\end{array}$} \\
\hline & & ELISA & rELISA & IHA & IFA & FeSOD & & \\
\hline Santiago de Querétaro & Rancho el Pitayo & 1 & 1 & 1 & 1 & 1 & 1 & 31 \\
\hline \multirow[t]{2}{*}{ Arroyo Seco } & Tanchanaquito & 1 & 1 & 0 & 0 & 1 & 1 & 22 \\
\hline & El Rejalgar & 1 & 1 & 0 & 0 & 1 & 1 & \\
\hline \multirow[t]{3}{*}{ Pinal de Amoles } & Las Adjuntas & 2 & 0 & 2 & 2 & 2 & 2 & 60 \\
\hline & Barranca del Plátano & 2 & 1 & 1 & 1 & 2 & 2 & \\
\hline & El Plátano & 1 & 1 & 1 & 1 & 1 & 1 & \\
\hline Landa de Matamoros & La Aguita & 3 & 1 & 1 & 1 & 3 & 3 & 3 \\
\hline \multirow[t]{2}{*}{ Peñamiller } & Alamitos & 3 & 2 & 2 & 2 & 3 & 3 & 87 \\
\hline & El Pilón & 4 & 2 & 3 & 3 & 4 & 4 & \\
\hline \multirow[t]{2}{*}{ Cadereyta } & Boyecito & 8 & 5 & 3 & 3 & 7 & 8 & 218 \\
\hline & Llanitos & 7 & 4 & 3 & 3 & 7 & 7 & \\
\hline \multirow[t]{3}{*}{ Tolimán } & Panales & 2 & 2 & 2 & 2 & 2 & 2 & 290 \\
\hline & San Pablo & 4 & 2 & 2 & 2 & 4 & 4 & \\
\hline & Horno de Cal & 2 & 1 & 2 & 2 & 2 & 2 & \\
\hline \multirow[t]{2}{*}{ Colón } & El Gallo & 11 & 9 & 11 & 11 & 11 & 11 & 122 \\
\hline & Viborillas & 1 & 1 & 0 & 0 & 1 & 1 & \\
\hline \multirow[t]{3}{*}{ El Marqués } & San Vicente Ferrer & 9 & 5 & 4 & 4 & 9 & 9 & 109 \\
\hline & Atongo & 2 & 2 & 3 & 3 & 2 & 2 & \\
\hline & Tierra Blanca & 2 & 1 & 0 & 0 & 2 & 2 & \\
\hline \multirow[t]{3}{*}{ Huimilpan } & Guadalupe 1 & 1 & 0 & 0 & 0 & 1 & 1 & 27 \\
\hline & Las taponas & 1 & 1 & 1 & 1 & 1 & 1 & \\
\hline & Santa Teresa & 1 & 1 & 1 & 1 & 1 & 1 & \\
\hline San Juan del Río & San Juan del Río & 9 & 6 & 10 & 10 & 9 & 9 & 49 \\
\hline \multirow[t]{2}{*}{ Corregidora } & Alfayúcan & 1 & 1 & 1 & 1 & 1 & 1 & 15 \\
\hline & Joaquín Herrera & 1 & 1 & 0 & 0 & 1 & 1 & \\
\hline Total & - & 80 & 62 & 54 & 54 & 80 & 80 & 1,033 \\
\hline
\end{tabular}

new diagnostic tool is considered, the iron superoxide dismutase (FeSOD). IFA: indirect immunofluorescence assay; IHA: indirect haemagglutination assay; rELISA: recombinant ELISA. 


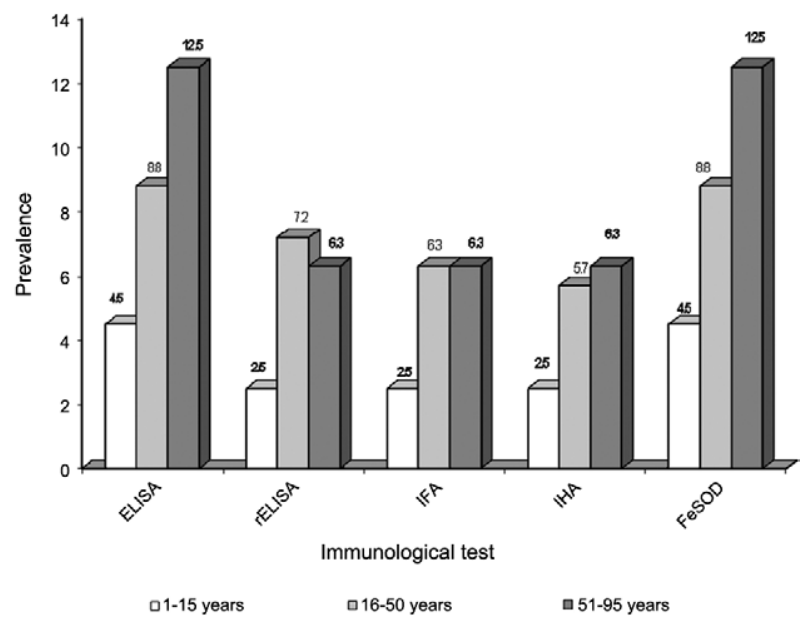

Fig. 2: prevalence of Trypanosoma cruzi seropositivity according to age group. FeSOD: iron superoxide dismutase; IFA: indirect immunofluorescence assay; IHA: indirect haemagglutination assay; rELISA: recombinant ELISA

collagen vascular diseases, is common (Carvalho et al. 1993, Bottino et al. 2013, Guevara et al. 2013). This crossreactivity inspired us to conduct a study of five different serologic tests to determine the statistical concordance among these tests and identify the true seroprevalence rate, as has been previously described by the WHO (Foti et al. 2009). The results are shown in Table II.

The statistical correlation rates between the five immunological tests were $8 \%$ between ELISA and FeSOD, $6.2 \%$ between ELISA and rELISA and $5.4 \%$ between IHA and ELISA-ELISA-IFA, showing that the sensitivity and specificity varied considerably. However, this variability can be attributed to technical problems. For example, recent recommendations suggest the use of fresh sera and avoiding freezing and thawing samples that will be used for rELISA because sensitivity with respect to IHA is lost. IHA does not work with antigenic extracts of $T$. cruzi strains that are obtained from humans; this test uses sensitised erythrocytes from sheep blood with antigenic extracts of the epimastigote forms of cultured $T$. cruzi, which reduces sensitivity and speci-

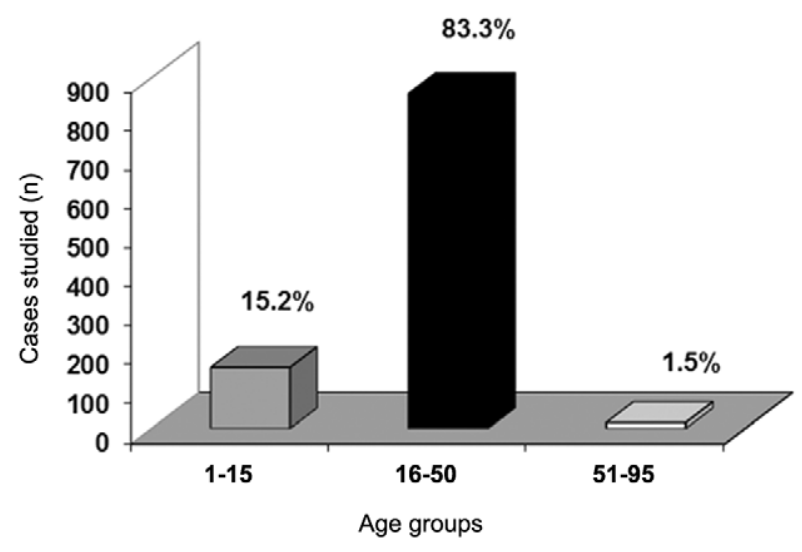

Fig. 3: percentages of age groups in the studied population.

ficity. The predictive values and kappa index confirmed the usefulness of performing two immunological tests for the detection of possible infections with this haemoflagellate parasite.

Seroprevalence according to age showed that seropositivity decreases in increments as age increases. The survey also showed that infection is often present at a very young age, which implies the establishment of the vector in the risk zone (Fig. 2).

A total of $8.8 \%$ of seroreactive inhabitants were of reproductive age and they performed various activities. Therefore, a socio-economic problem arises when these inhabitants become infected because they are part of the economic support of their families. Most of the subjects in this study were women (74\%) and only $26 \%$ were men.

The majority of individuals sampled in this study $(83.3 \%)$ were between the ages of $16-50$ years old. This population often moves to other areas for work, study or leisure and they are considered high risk. Subjects between one- 15 years of age made up $15.2 \%$ of the sample and subjects between $51-95$ years old constituted $1.5 \%$ of the sample (Fig. 3).

Most of the population (99.3\%) did not travel outside their communities and remained in the same locality for their entire lives. Additionally, the majority of the

TABLE II

Statistical correlation between the five immunological tests used in the study with the enzyme Western blots-iron superoxide dismutase (FeSOD) match is $100 \%$

\begin{tabular}{lcccccc}
\hline Assays & $\begin{array}{c}\text { Sensitivity } \\
(\%)\end{array}$ & $\begin{array}{c}\text { Specificity } \\
(\%)\end{array}$ & $\begin{array}{c}\text { PPV } \\
(\%)\end{array}$ & $\begin{array}{c}\text { NPV } \\
(\%)\end{array}$ & $\begin{array}{c}\text { Concordance } \\
(\%)\end{array}$ & $\begin{array}{c}\text { Kappa } \\
\text { index }\end{array}$ \\
\hline ELISA r-ELISA & 75.6 & 99.9 & 98.5 & 98 & 98 & 0.8 \\
ELISA-IFA & 68.2 & 99.9 & 98.3 & 97 & 97 & 0.8 \\
ELISA-IHA & 63.5 & 100 & 100 & 97 & 97 & 0.8 \\
ELISA-FeSOD & 94.4 & 100 & 98.4 & 98 & 100 & 0.96 \\
\hline
\end{tabular}

IFA: indirect immunofluorescence assay; IHA: indirect haemagglutination assay; NPV: negative predictive values; PPV: positive predictive values; rELISA: recombinant ELISA. 
TABLE III

Percentage of the types of material that forms part of ceilings, walls, fences and floors wthat are part of the construction of the houses of seropositive individuals studied

\begin{tabular}{lccccccccc}
\hline Material & $\begin{array}{c}\text { Straw } \\
(\%)\end{array}$ & $\begin{array}{c}\text { Sheet } \\
(\%)\end{array}$ & $\begin{array}{c}\text { Cardboard } \\
(\%)\end{array}$ & $\begin{array}{c}\text { Wood } \\
(\%)\end{array}$ & $\begin{array}{c}\text { Clay } \\
(\%)\end{array}$ & $\begin{array}{c}\text { Adobe } \\
(\%)\end{array}$ & $\begin{array}{c}\text { Ground } \\
(\%)\end{array}$ & $\begin{array}{c}\text { Concrete } \\
(\%)\end{array}$ & $\begin{array}{c}\text { Stone } \\
(\%)\end{array}$ \\
\hline Roof & 70 & 70 & 70 & 20 & - & - & - & 10 & - \\
Wall & 88 & - & 15 & 15 & 10 & 10 & - & - & 90 \\
Ground & 50 & - & - & - & - & - & 50 & 60 & 50 \\
\hline
\end{tabular}

population (98\%) cohabited with animals and $8.7 \%$ had symptoms of infection, according to the survey that was performed at the beginning of the study.

The type of housing played an important role in the epidemiology of the infection because building materials constitute an important variable in the establishment of the vector. Details regarding the housing type are summarised in Table III.

The only statistically significant difference noted in this study was in the percentage of the different tests that were reactive, relative to symptomatology (Fig. 4).

The Official Mexican Norm (NOM 1999) regarding blood testing for Chagas disease (NOM-033.SSA1-1997) mentions only that assays must be performed in cities in geographical areas where Chagas is endemic. The results obtained between ELISA-FeSOD was 8\%, which indicates that infection by $T$. cruzi in Querétaro is five times higher than the national average of 1.6\% (GuzmánBracho 2001). The $8 \%$ seropositivity rate means that 84

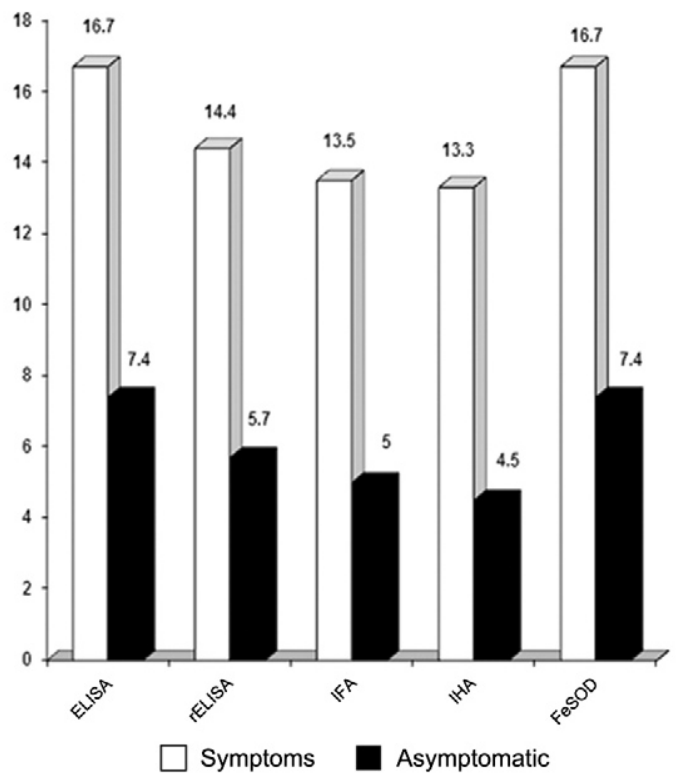

Fig. 4: percentage of reactive cases in the relation to the different assays. FeSOD: iron superoxide dismutase; IFA: indirect immunofluorescence assay; IHA: indirect haemagglutination assay; rELISA: recombinant ELISA. individuals are reactive. If this rate is extrapolated to the entire population, an estimated 40,000 persons are infected, $30 \%$ of whom will develop cardiac disease in the next 15-20 years. It is important to mention that Querétaro should be considered an endemic area because our results reflect a high percentage of high-risk individuals and there is active transmission of infection (15.2\% age paediatric). The results have been reported to the Health Services of the State of Querétaro. We were also able to establish ELISA as the test of choice for the detection of anti-T. cruzi antibodies for all persons who donate blood at the State Centre of Haemotherapy. Testing for T. cruzi should not be reserved for individuals from endemic areas, despite possible controversy.

Similarly, the results obtained with ELISA and FeSOD testing, which are sensitive and specific for genus and species, found that the use of an enzyme-extracted parasite as the antigen (instead of antigenic extracts of epimastigote forms and/or trypomastigotes) cross-reacted with other aetiological agents; this technique should therefore be avoided because of the risk of false positive findings.

New diagnostic techniques, such as the superoxide dismutase technique, have been designed as confirmatory tests to overcome this problem. The superoxide dismutase assay is the only diagnostic approach that can identify anti-T. cruzi antibodies (Villagrán et al. 2005). It should be used in blood banks as the only definitive diagnostic test for the detection and confirmation of reactive Chagas infection and can eliminate the need to perform second and third tests for the disease (Wendel \& Leiby 2007, Villagrán et al. 2009).

The collected data show active transmission of $T$. cruzi in Querétaro, which was not previously considered an endemic zone.

\section{REFERENCES}

Araújo AB, Berne MEA 2013. Conventional serological performance in diagnosis of Chagas disease in southern Brazil. Braz J Infect Dis 17: 174-178.

Bacigalupo J 1945. Enfermedad de Chagas y transfusión sanguínea. El día del Médico 20: 425.

Berrizbeitia M, Figueroa M, Ward BJ, Rodríguez J, Jorguera A, Figuera MA, Romero L, Ndao M 2012. Development and application of an ELISA assay using excretion/secretion proteins from epimastigote forms of T. cruzi (ESEA antigens) for the diagnosis of Chagas disease. J Trop Med 2012: 875909. 
Bottino CB, Gomes LP, Pereira JB, Coura JR, Williams PJ, De-Simone S 2013. Chagas disease-specific antigens: characterization of epitopes in CRA/FRA by synthetic peptide mapping and evaluation by ELISA-peptide assay. BMC Infect Dis 13: 568.

Camargo ME, Segura BI, Kagan IG, Souza I, Cabalheira JR, Guimaraes MCS 1986. Three years of collaboration on the standardization of Chagas disease serodiagnosis on the American Continent. An appraisal. Bull Pan Am Health Organ 20: 233-244.

Carvalho MR, Krieger M, Almeida E, Oeleman W, Shikanai M, Ferreira A, Pereira JB, Saez A, Dorehiac PE, Chamone D, Goldenberg S 1993. Chagas disease diagnosis: evaluation of several tests in blood screening. Transfusion 33: 830-834.

Castro E 2009. Chagas disease. Lessons from routine donation testing. Transfus Med 19: 16-23.

CETS - Centro Estatal de la Transfusión Sanguínea Secretaria de Salud/Santiago de Querétaro 2002. Estadísticas del Banco de Sangre. Available from: seseq.gob.mx.

Días E 1945. Um ensaio de profilaxia de moléstia de Chagas: relatório sobre o $1^{\circ}$ semestre de atividades do Centro de Estudos e Profilaxia da Moléstia de Chagas de Bambuí, Estado de Minas Gerais, Imprensa Nacional, Rio de Janeiro.

Faria P 1951. Sífilis, maleita, doença de Chagas e transfusão. Folia Clin Biol 17: 113-117.

Ferrer E, Lares M, Vietrri, Medina M 2013. Comparison between immunological and molecular techniques for the diagnosis of Chagas disease. Enferm Infecc Microbiol Clin 31: 277-282.

Foti L, Fonseca BPF, Nascimento LD, Marques CFS, da Silva ED, Duarte CAB, Probst CM, Goldenberg S, Pinto AG, Krieger MA 2009. Viability study of a multiplex diagnostic platform for Chagas disease. Mem Inst Oswaldo Cruz 104 (Suppl. I): 136-141.

Freitas JLP, Amato V, Sonntag R, Biancalana A, Nussenzweig V, Barreto JG 1952. Primeiras verificações de transmissão acidental da moléstia de Chagas ao homem por transfusão de sangue. Rev Paul Med 40: 36-40.

Guevara AG, Atherton RD, Wauters MA, Vincaña Y, Nelson M, Prado J, Kato H, Calvopiña MH, Hashiguchi Y 2013. Seroepidemiological study of Chagas disease in southern Amazon of region of Ecuador. Trop Med Health 41: 21-25.

Guzmán-Bracho C 2001. Epidemiology of Chagas disease in México: an update. Trends Parasitol 17: 372-376.

Guzmán-Bracho C, García L, Verdugo J, Martínez S, Cosme M, Castrejón O 1998. Riesgo de transmisión de Trypanosoma cruzi por transfusión de sangre en México. Rev Panam Salud Publica 4: 94-98.

Kirchhoff LV, Neva FA 1985. Chagas disease in Latin American immigrants. JAMA 254: 3058-3060.

Longhi SA, Brandariz SB, Lafón SO, Niborski LL, Luqueti AO 2012. Evaluation of in-house ELISA using Trypanosoma cruzi lysate and recombinant antigens for diagnosis of Chagas disease and discrimination of its clinical forms. Am J Trop Med Hyg 87: 267-271.

Lorca M, Thierman E, Bergen AM 1990. Técnica de ELISA IgG e IgM en el diagnóstico de la enfermedad de Chagas aguda. II Evaluación diagnóstica del método. Parasitol Día 14: 3-9.
Marín C, Sánchez-Moreno M 2010. Excreted/Secreted antigens and the diagnosis of Chagas disease. In E Jirillo, O Brandonisio (eds.), Inmmune response to parasitic infections 1, Bentham eBooks, São Paulo, p. 10-20.

Mazza S, Montana A, Benitez C, Juzin E 1936. Transmisión de Schizotrypanum cruzi al niño por leche de la madre con enfermedad de Chagas. MEPRA 28: 41-46.

Miles M 2004. The discovery of Chagas disease: progress of a prejudice. Infect Dis Clin North Am 18: 247-260.

Monteón-Padilla VM, Hernández-Becerril N, Guzmán-Bracho C, Rosales-Encina JL, Reyes-López PA 1999. American trypanosomiasis and blood banking in Mexico city: seroprevalence and its potential transfusional transmission risk. Arch Med Res 30: 393-398.

NOM - Norma Oficial Mexicana 1999. Norma oficial mexicana para la vigilancia epidemiológica, Diario Oficial de la Federación DLIII (NOM-017-SSA2), p. 53-80.

Nussenzweig V, Sonntag R, Biancalana A, Freitas JLP, Amado Neto V 1953. Ação da colorantes tri fenil metanicos sobre o Trypanosoma cruzi "in vitro". Emprego da violeta de genciana na profilaxia da transmissão da moléstia de Chagas por transfusão de sangue. Hospital (Rio J) 44: 731-744.

OMS - Organización Mundial de la Salud 1990. Las condiciones de salud en las Américas, Publicación Científica 524, OMS, 450 pp.

OMS - Organización Mundial de la Salud 1991. Control de la enfermedad de Chagas, Serie de informes técnicos, Informe de un Comité de Expertos de la OMS, OMS, 101 pp.

OPS - Organización Panamericana de la Salud 1993. Iniciativa del Cono Sur. In Proceedings of the 2nd Reunión de la Comisión Intergubernamental para la eliminación de Triatoma infestans y la interrupción de la tripanosomiasis americana transfusional, 4 Oct 1993, Santa Cruz de la Sierra, p. 243-249.

Pellegrino J 1949. Transmissão da doença de Chagas pela transfusão de sangue. Primeiras comprovações sorológicas em doadores e candidatos a doadores de sangue. Rev Bras Med 6: 297-301.

Talice RV 1947. Curso de hemoterapia. Central de Sangre y Plasma de la Facultad de Medicina de Montevideo/Biblioteca de la Cátedra de Medicina transfusional/Imprenta Rosgal, Montevideo.

Villagrán ME, Marín C, Hurtado A, Sánchez-Moreno M, de Diego JA 2008. Natural infection and distribution of triatomines (Hemiptera: Reduviidae) in the state of Querétaro, Mexico. Trans $R$ Soc Trop Med Hyg 102: 833-838.

Villagrán ME, Marín C, Rodríguez-González I, de Diego JA, Sánchez-Moreno M 2005. Use of an iron superoxido dismutase excreted by Trypanosoma cruzi in the diagnosis of Chagas disease: seroprevalence in rural zones of the state of Querétaro. Am J Trop Med Hyg 73: 510-516.

Villagrán ME, Sánchez-Moreno M, Marín C, Uribe M, de la Cruz JJ, de Diego JA 2009. Seroprevalence to Trypanosoma cruzi in rural communities of the state of Querétaro (Mexico), statistical evaluation of test. Clin Biochem 42: 12-16.

Wendel S, Leiby DA 2007. Parasitic infections in the blood supply: assessing and countering the threat. Dev Biol (Basel) 127: 17-41. 